\title{
African Migrant Narratives, Modern Slavery, and Human Rights Violations in Libya
}

Lady Adaina Ajayi (Covenant University, Nigeria), Anijesushola O. Ajayi (Covenant University, Nigeria), Sheriff F. Folarin (Covenant University, Nigeria), Abdulrahman Oluwaseyi Tiamiyu (Covenant University, Nigeria), Chioma Eucharia Nnajidema (Covenant University, Nigeria) and Oluwaseyi Emmanuel Ogunnowo (Covenant University, Nigeria)

Source Title: Handbook of Research on the Global Impact of Media on Migration Issues

Copyright: (C) 2020 Pages: 20

DOI: 10.4018/978-1-7998-0210-5.ch004

OnDemand PDF Download:

Available

$$
\$ 37.50
$$

Current Special Offers

\begin{abstract}
Libya has served as the entrepôt for the modern slave trade from Africa to Europe for many decades. In recent years, however, international bodies, as well as the media, have raised deep concerns on the unimaginable horrors SubSaharan African migrants are forced to witness and experience during their stay and transit through Libya. It is against this background that this study through the 'narrative research approach' sought to examine the various patterns of human rights violations experienced by African migrants in Libya as well as the role of the media in exposing the horrific trends of modern slavery. The study finds horrific patterns of human right violations perpetuated by both state and non-state actors in Libya. In addition, the media has played significant roles in serving as a major and reliable source of information on this phenomenal migration of the new age as well as a mediating body between policymakers and migrants. However, the complacency of governments whose citizens have and are being abused represents a more complex migration issue that needs to be addressed.
\end{abstract}

$\underline{\text { Top }}$

Chapter Preview

\section{Introduction}

For many decades- perhaps even centuries- Libya has served as the entrepôt for the modern slave trade from Africa to Europe. In fact, Libya has distinguished itself too, as an important destination. The illicit slave-economy in Libya has long been sustained by a complex web of migrant-smuggling and enslavement of Black Africans (Shaw and Mangan, 2014). The trade was necessary to recoup, or support the Libyan economy in the face of the protracted civil war (Abuhadra and Tawfik, 2014). In fact, there existed and still exists, a well-established smuggling infrastructure that brings people across the Sahara into Libya. The routes and networks used to move migrants are controlled by semi-nomadic tribes along Libya's southern borders.

In recent years, reports indicate that Libya has become a destination and transit country for men and women from Sub-Saharan Africa subjected to forced labour and sex trafficking while its young population is exposed to recruitment by several armed groups within the country. Government instability in the country and perhaps its absence in certain areas have resulted in increasing human trafficking crimes and profiteering from the illicit trade. These trafficking victims are men, women and children and they are susceptible to extreme violence and other human rights violations. Such abuses include physical, sexual, and verbal assault; snatching for the payoff; brutal killings; starvation; and illegal detention in camps perpetuated by the Libyan government officials and non-state actors (Women's Refugee Commission, 2019; Wallis, 2019; United States Department of States, 2018; International Organisation for Migration [IOM], 2017). 
According to International Organisation for Migration [IOM] (2017), it is estimated that between 700000 and 1, 000 , 000 migrants are stuck in Libya. Furthermore, there is the concern that an overwhelming majority of these population belong to Sub-Saharan and North African countries including Nigeria, Niger, Chad, Sudan, Ghana and Egypt among others. Additionally, it has also been reported that these Sub-Saharan migrants often go through racial discrimination and extreme human rights violations, which successive governments have failed to address (Leghtas, 2018). The Committee on the Elimination of Racial Discrimination (2017) as well as Cable News Network [CNN] (2017) raised the issue that black men were being sold in Libyan slave markets while black women were being forced to undergo physical and emotional torture through serial cases of sexual abuse and gender-based violence.

Female migrants have been particularly defenceless against rape by the traducers and runners along the movement or trade routes to Libya. There are accessories such as prostitution rings that allegedly subject Sub-Saharan women and a few young ladies to sex dealings in massage parlours, especially in southern Libya. Nigerian female migrants, specifically, were more subjected to forced prostitution. This was corroborated by Juliette, a Cameroonian migrant who stated that "when someone kidnaps you, he can call his brothers (to tell them he has women and girls). In front of me, men came to take girls away to rape them, especially Nigerian girls" (Leghtas, 2017:12; Mafu, 2019; Kirkin \& Anderson, 2018). In 2015 and 2016, the terrorist organisation, Islamic State of Iraq and Syria (ISIS) in Libya kidnapped at least five hundred and forty (540) migrants and refugees among whom were no fewer than sixty-three (63) women forced into sexual slavery for its fighters (United States Department of State, 2018). The reports on the occurrence of such incidents reduced after the defeat of ISIS across most of eastern Libya. 